\title{
A Social Cost-Benefit Analysis of the Vehicle Restriction Policy for Reducing Overtourism in Udo, Korea
}

\author{
Suah Kim and Namjo Kim * \\ Department of Tourism, Hanyang University, Seoul 04763, Korea; kimsua@hanyang.ac.kr \\ * Correspondence: njkim@hanyang.ac.kr; Tel.: +82-1042-8040-03
}

Received: 12 December 2019; Accepted: 13 January 2020; Published: 14 January 2020

\begin{abstract}
Overtourism has given rise to conflict among various stakeholders. Accordingly, to control overtourism, the public sector has started to implement policies. Recently, Udo off Jeju Island in South Korea has begun experiencing overtourism; to prevent the situation from deteriorating, the public sector implemented a vehicle restriction policy. This study used a cost-benefit analysis framework to assess the social costs and benefits of the public policy to control overtourism in Udo. Through interviews and relevant data and documents, this study classified analysis items related to the policy that could be either a cost or benefit to different stakeholders. The social cost-benefit analysis showed that the net benefit increases, the longer the policy continues, thus ensuring it is adequate and feasible to implement the policy. An effective management public policy for the sustainability of the region's tourism should always be promoted.
\end{abstract}

Keywords: overtourism; crowding; social cost-benefit analysis; tourism economy; sustainable tourism; tourism public policy; stakeholders

\section{Introduction}

"Overtourism" has emerged as a global concern, with tourism growth having a profound effect on local communities. Regions cited as typical examples of overtourism are Venice, Barcelona, and Boracay. The negative effects of garbage, noise, and traffic congestion are more than these regions can handle. In South Korea, overtourism can be observed in Bukchon Hanok Village, Jeonju Hanok Village, Yeosu, and Udo island—an island accessible from Jeju, special self-governing province (hereafter "Jeju province").

The overtourism problem is not restricted to congestion caused by tourists. Local residents are known to have been displaced due to the rising prices of commodities, as well as of real estate-side effects of the gentrification of tourist areas. The commodities they need daily are often replaced in shops as the latter start to cater more to tourists' commodity needs, such as souvenirs. As the damage to the local residential environment grows, the local people who experience problems daily may start protesting and develop hatred towards tourists—commonly referred to as "tourism phobia"—and may even turn to a crime against tourists. In recent years, it has not only been local residents that have repudiated excessive tourism but the tourists themselves who eschew these crowded tourism spots [1].

When considering the overtourism problem, the concerns that arise often involve multiple stakeholders, each with their various interests that are determined by their respective economic, social, and political interests [2]. These interests, which are often contradictory, also make it difficult to draw a social consensus and arrive at a comprehensive solution when overtourism-related problems occur.

To decrease conflicts caused by overtourism, the public sector has started to implement policies to control the overtourism phenomenon. World travel and tourism council developed a diagnostic 
index for overtourism, which can be adjusted and applied according to the region's situation, with the intention to solve excessive congestion and promote sustainable tourism [3]. For example, starting in 2015, Barcelona transitioned to management-oriented tourism policy, rather than seeking ways to further promote their tourism attractions. In Venice, resident-oriented convenience policies are also being prepared to control the number of tourists per day.

As mentioned above, South Korea is also currently experiencing overtourism. This study examined the overtourism phenomena occurring in Udo island off Jeju island in South Korea. Among the many overtourism phenomena occurring there, traffic accidents and traffic congestion have intensified significantly. A policy was introduced to restrict the number of vehicles allowed onto Udo island. However, even though it was introduced in a timely manner, conflicts arose among society members who were stakeholders in upholding and "policing" this policy.

In fact, the situation became such that the local merchants of Udo island sued Jeju province, citing the loss of revenue that they would suffer because of the decrease in tourists expected from the inconvenience of not being able to use a personal car on the island. Specifically, they filed a lawsuit against Jeju province in July 2017 against the vehicle restriction policy (hereafter VRP) on Udo island, asking for "the suspension of the execution of the car operation and traffic restriction order and the cancellation of the administrative order." In April 2018, the court rejected this request [4]. Local residents also supported the policy's implementation because it would improve traffic congestion, as well as the convenience of their daily life. This situation highlights the emergence of various stakeholder interests and opinions, which are often contradictory in nature.

This study performed an economic cost-benefit analysis of the aforementioned VRP for Udo island, a small island belonging to Jeju Island in South Korea. There are 1817 residents living on Udo. The area of the island is $6.18 \mathrm{~km}^{2}$ and the coastline is $19.8 \mathrm{~km}$ long. The VRP was implemented as a domestic policy to assist in coping with overtourism that was causing various negative effects on the island. This study examined what the various stakeholders might gain and lose from the implementation of this VRP aimed at diverting overtourism on Udo island, thereby assisting in creating a body of literature in support of the "anti-overtourism" policy. Results from this study might provide insight into the appropriateness and necessity of anti-overtourism policy creation and implementation in other regions with similar conditions.

\section{Theoretical Background}

\subsection{Overtourism}

Overtourism is a growing phenomenon, attracting attention in the tourism field globally. It is a compound word derived from the two words "over" and "tourism" and is not recognized at present as an academic term. The term "overtourism" was first used in 2012 on Twitter by Harold Goodwin, a professor at Manchester Metropolitan University. It was used to refer to the problems being faced in European cities, such as Barcelona, Spain, and Venice, where tourism was being negatively affected [5]. Since then, it has been frequently used in the media and was even officially used at the United Nations World Tourism Organization (UNWTO) and World Travel Market (WTM) ministerial conference in 2017 [6].

According to Goodwin, overtourism is the opposite of "responsible tourism". It means that "the quality of life, or the quality of the experience in the area, has deteriorated extremely because of too many visitors to the area". "Overtourism" is a negative phenomenon, caused by a plethora of tourist visitors and is classified alongside "tourist phobia" and "touristification" [7].

According to a UNWTO report, the main factors contributing to overtourism are excessive visitors possibly aggravated by seasonality, uncurbed adverse visitor effects, and unrestrained physical effects from the visitor economy [8]. The economic, environmental, and socio-cultural effects considered when evaluating "sustainable tourism" in a region are all negative in a community experiencing "overtourism". Lee stated that media related to this phenomenon could be identified through terms, 
such as "overtourism", "overcrowding", "infringement of local people's rights", "touristification", "tourist phobia", and even "McDonald tourism".

These phenomena not only negatively affect local residents, but they also deprive tourists of an authentic experience. Thus, overtourism can be seen as having adverse effects both on local residents and tourists simultaneously [9].

The World Travel and Tourism Council (WTTC) states that "overtourism" occurs during the high season and at specific times of the day when tourist visits are concentrated [3]. The symptoms or effects of overtourism vary from region to region, depending on the nature of the destination. It is necessary to actively manage this problem, take measures, and even intervene politically for the development of sustainable tourism.

In addition, the rise of overtourism is seen as a failure of the tourism system and recognized as a problem in inter-element interaction rather than a problem of elements of the tourism system [10]. In other words, mutual efforts between the tourism subjects ("tourists"), the tourism objects ("attractions"), and the media are essential for sustainable and socially responsible development.

Overtourism is not a problem that will disappear any time soon and is a global phenomenon [11]. As such, critical discussion is needed to manage this emerging phenomenon to develop sustainable tourism [3,8-12].

\subsection{Green Transport Policy for Sustainable Tourism}

While tourism is growing continuously, the impact of $\mathrm{CO}_{2}$ on climate change due to tourism activities, such as traffic, is relatively large compared to other sectors [13]. Technology development alone cannot help reduce $\mathrm{CO}_{2}$ emissions [14]. The principle of sustainable tourism development should be applied to various types of tourism activities and to tourism management by establishing both short and long-term strategies and programs [15]. Considering the significant influence of tourism and the need for rapid change, a sustainable action strategy to reduce $\mathrm{CO}_{2}$ emissions is urgently needed.

The tourism industry has contributed greatly to the global increase in greenhouse gas (GHG) emissions resulting from transportation, accommodation, and related activities [16-19]. In fact, the tourism industry accounts for about $5 \%$ of the world's $\mathrm{CO}_{2}$ emissions, but given the strong radiative power of GHG's, the overall contribution of tourism to the global warming potential is estimated at $5.2-12.5 \%$ [17]. It should be noted that $72 \%$ of the $\mathrm{CO}_{2}$ emissions from tourism come from transportation, $24 \%$ from the accommodation, and $4 \%$ local activities [16]. The $\mathrm{CO}_{2}$ emissions from transportation of tourism are followed by air travel, accounting for $40 \%$, and automobiles, accounting for $32 \%$ [19].

Sustainable tourism is closely related to sustainable mobility because transportation is its inherent component. Therefore, it is urgent to upgrade existing public transportation and introduce green cars (e.g., electric cars or hybrid cars) to achieve sustainable mobility [16]. Cycling is also perceived by visitors as a positive way to utilize leisure time and as an essential part of one's travel or holiday [20]. In areas where tourism is active, it is important to ensure sustainable mobility suitable for the region in the long term.

The goal of sustainable tourism is to mitigate the negative impact of tourism by increasing the associated benefits [21]. The most urgent tasks include addressing high energy consumption, food waste, waste management, and vulnerable business environments (especially in developing countries) [16]. It is vital that tourism and transportation subsectors consume high energy and have a great impact on climate change be managed.

Public sectors responsible for tourism management are focusing on policies that utilize green transportation. Against this background, studies have analyzed the impact of tourism on climate change due to transportation using air and automobiles [13,14,17,19]. Cost-benefit analyses have been conducted primarily to support the introduction and evaluate the feasibility of green transportation [20-23]. However, these studies did not analyze the potential profits from green transportation; rather, they examined how to derive social benefits from it, with the aim of verifying 
the legitimacy of a policy meant to secure regional sustainability by establishing a green transportation system that restricts the entry of vehicles.

\subsection{The Vehicle Restriction Policy in Udo, South Korea}

Limiting vehicle entry is the dominant policy in South Korea, which is used to address problems due to overtourism - excess garbage, traffic congestion, destination congestion, and conflict between local residents and merchants.

In the early 2000s, Udo was a quiet island. However, the number of domestic and Chinese tourists has increased rapidly since 2007, causing various problems (Table 1). To solve the problem, the Jeju province implemented a cap on the total number of vehicles that limit the introduction of external vehicles on the island itself by considering not only their physical carrying capacity but also their social carrying capacity [24]. Since 2008, only 605 vehicles have been allowed onto the island per day during the peak summer season (July to August), but this restriction has not been observed because of the non-cooperative attitude of the shipping operators in Udo [25].

Since then, the number of visitors to Udo island has increased continuously. From August 2015 to July $2016,1,408,598$ people visited Udo, increasing by $15.3 \%$ from 1,221,552 people visited during the same period last year, from August 2014 to July 2015. At that time, traffic and environmental problems became more serious as an average of 8900 tourists visited Udo island per day, where about 1700 people lived. More than 4 tons of garbage was generated every day in areas where only 1.5 tons could be disposed of through incineration. There were 58 traffic accidents in 2013, 67 in 2014, and 70 in 2015 in an area of just $0.05 \mathrm{~km}^{2}$ [26].

Jeju province has established comprehensive measures for Udo island-which is accessible only from Jeju-limiting the number of cars permitted onto the island to solve the traffic problem. The Udo love cooperative association (hereafter ULCA), a community-based tourism organization founded by local residents, has introduced 20 electric buses and 15 charter buses since the implementation of the policy in January 2018 [27].

There has been a great deal of conflict over this policy, which has achieved the tangible goal of reducing traffic during the policy implementation period. Nevertheless, Jeju province wants to actively implement the VRP in the long term to achieve the vision of the "sustainable coexistence of tourists and local residents seeking access to the island" and is attempting to minimize possible inconveniences caused by the restriction policy. Therefore, it is necessary to analyze the practical costs and benefits of implementing this policy to ensure that it is reliably implemented.

In addition, Jeju province has already been actively cooperating with both public and private sectors for more than a decade to make the island carbonless and promote sustainable development. The Udo island policy, restricting the entry of vehicles, serves not only to reduce traffic accidents but also to gain recognition as a sustainable tourist destination where tourists and residents can coexist on a green island with no excess carbon emissions.

Therefore, this study examined the VRP as a policy intended to transform Udo into a carbon-free island. Meanwhile, the Jeju province is aware of the overtourism on Udo and is simultaneously managing traffic volume and the inflow of tourists by restricting vehicle entry. 
Table 1. The Process of Implementing the Vehicle Restriction Policy on Udo Island.

\begin{tabular}{|c|c|}
\hline Year & The Main Process Content \\
\hline 2000 & $\begin{array}{l}\text { Domestic and Chinese tourists surged because of the promotion of the island as a tourist } \\
\text { destination by the South Korean central government. }\end{array}$ \\
\hline 2007 & $\begin{array}{l}\text { A number of media comments and related complaints appeared about the increase in traffic } \\
\text { accidents on Udo. }\end{array}$ \\
\hline 1 July 2009 & $\begin{array}{l}\text { Jeju province calculated the size of traffic demand management, which reflected the total area } \\
\text { of the island and the traffic situation, and restricted the total number of vehicles entering Udo. }\end{array}$ \\
\hline 2010-2015 & $\begin{array}{l}\text { Lack of legal grounds, poor implementation of the total vehicle volume system because of the } \\
\text { uncooperative attitude of shipping operators in Udo. }\end{array}$ \\
\hline 2016 & Jeju province built a task force team to prepare transportation measures for Udo island. \\
\hline \multirow[t]{2}{*}{2017} & $\begin{array}{l}\text { The establishment of a legal basis. } \\
\text { An exceptional case of restrictions on the operation of automobiles in the 'special act on the } \\
\text { establishment of Jeju province and the development of free international city' restrictions on } \\
\text { the operation of a car in the 'automobile management act'. }\end{array}$ \\
\hline & $\begin{array}{l}\text { Establishment of three levels of transportation measures in Udo based on legal grounds. } \\
\text { Level 1: No new car rental businesses in Udo. } \\
\text { Level 2: } 30 \text { out of } 100 \text { rental cars are transferred to the main island for self-decreasing vehicles } \\
\text { in Udo. Two-wheelers and electric motorcycles were reduced from } 300 \text { to } 270 \text {. } \\
\text { Level 3: Some vehicle restriction orders in Udo. }\end{array}$ \\
\hline 12 May 2017 & $\begin{array}{l}\text { Announcement of these vehicle restriction orders in Udo } \\
1 \text { August 2017-31 July } 2018\end{array}$ \\
\hline 1 March 2018 & $\begin{array}{l}\text { Change in vehicle restriction policy } \\
\text { Accommodation guests and visitors accompanied by children under the age of 5, the } \\
\text { transportation vulnerable, and pregnant women are allowed to enter the island with a vehicle. }\end{array}$ \\
\hline 1 August 2018 & Extension of some vehicle restriction orders in Udo. \\
\hline
\end{tabular}

Note: Researchers conducted interviews with the person in charge of Udo's vehicle restriction policy and organized it by referring to the announcement of restrictions on the operation of some cars on the island [28].

\subsection{Social Cost-Benefit Analysis in Tourism}

The VRP contributes to reducing environmental problems in Udo's dominant community. Mitigating traffic congestion and establishing social order are examples of externalities that can increase the benefits to the local community. The social cost-benefit analysis enables a quantitative assessment of how important the VRP is to the dominant community.

The cost-benefit analysis for determining public policy implementation is called social cost-benefit analysis because it should be carried out in view of the effects on society as a whole, unlike the economic cost-benefit analysis conducted by individual firms [29-33]. If an economic cost-benefit analysis is a review of efficiency, then a social cost-benefit analysis is a review of equity, which is as important as efficiency $[34,35]$.

The social cost-benefit analysis should take into account both the negative and positive effects of public policies on society as a whole. The ultimate goal of public policy with regulatory characteristics is to realize social values, such as human rights, safety, welfare, social protection, environmental protection, safety, quality of life, economic growth, and employment [36]. This necessitates an analysis of the quantifiable direct effects of policy implementation, as well as of the indirect effects that are difficult to quantify. Therefore, both quantitative and qualitative analyses are needed, and in recent years, various techniques have been developed to measure these social values [33].

Ruijs described the role of social cost-benefit analysis in public project promotion and policymaking with five elements: providing insight into individual and overall effects; public discussion among stakeholders and decision-makers; improving transparency in decision making; communicating and explaining the results; and providing a framework for measuring influence with each other [37]. Jones-Lee and Aven also stated that a social cost-benefit analysis with adequate weights is appropriate in situations characterized by the uncertainty that cannot be predicted accurately [38]. This is why public works or policies can be justified through analysis, although it is difficult to construct objective 
indicators and calculate them financially to properly analyze social costs and benefits according to the target.

Until now, the study of social costs and benefits has mainly been implemented within the eco-tourism sector. As such, the costs and benefits of conservation have been the object of measure within ecotourism. From the study by Kirkby et al., which conducted a social cost-benefit analysis of land use in the Tambopata region of Peru, ecotourism is a successful monetization of nature's pleasure value (hedonic value), and the authors considered ecotourism a justification for the maintenance of intact rain forests [39]. After excluding the factors causing effects of eco-tourism on local culture and norms, they calculated carbon emissions from tourism and regarded it as social costs for eco-tourism and analyzed the social benefits of eco-tourism and carbon emission reduction resulting from eco-tourism, including the producer surplus-value of ecological tourism and alternative activities. This was the first study to calculate and compare the value of ecotourism to that of alternative land use activities.

In addition, social cost-benefit analysis is mainly conducted to review the feasibility of implementing development policies that take into account the value of the environment [40-45]. The costs of implementing development projects and policies are easy to quantify. By contrast, the concerns in the social cost-benefit analysis are the social benefits that have been affected by the policy and the calculation of the effects of environmental improvements, among others. This improvement effect-a social benefit-is currently being regarded as the benefit of reducing carbon emissions, and a system exists that can be used to assess the value of carbon per unit [39-41].

To measure the value of other benefits, the contingent valuation method (CVM) is mainly used to derive the net benefit of the present value, thereby ensuring the feasibility of a policy.

\section{Methods}

\subsection{General Methods}

\subsubsection{Economic Analysis: A Social Cost-Benefit Analysis Framework}

The economic analysis employs present value net benefit (PVNB), benefit/cost (B/C) ratio, and internal rate of return (IRR) as indices. However, when using the incremental cost-benefit ratio to determine an alternative priority in the $\mathrm{B} / \mathrm{C}$ ratio, the result is the same as the net benefit. Moreover, in IRR, the $n$ th-order equation is calculated according to the formula at the $n$th time so that the $n$th result can be varied [29]. Net benefit (Benefit-Cost, or NB) indicates economic feasibility. If NB is greater than zero, it means the policy is economically feasible.

The effect of policy differs by time, so one point in time must be set as the standard for evaluation. The reference point can be set in the present or future. When it is based on a future point, the setting of the last point is ambiguous, and the backward approach, or the present value method, is mainly used. The present value method evaluates policy by converting the benefits and costs of various items occurring at different times into present values. If the benefits converted to present values are greater than the corresponding costs, the policy is deemed effective; if the benefits in terms of present value are smaller than the corresponding costs, the policy is ineffective.

To evaluate future values in terms of present values, the total benefit and total cost are discounted by the value of the investment of time (discount rate) by applying Equations (1) and (2).

$$
\begin{gathered}
B i=\frac{B_{i 0}}{(1+r)^{0}}+\frac{B_{i 1}}{(1+r)^{1}}+\ldots+\frac{B_{i T}}{(1+r)^{T}}=\sum_{t=0}^{T} \frac{B_{i t}}{(1+r)^{t}} \\
C j=\frac{C_{j 0}}{(1+r)^{0}}+\frac{C_{j 1}}{(1+r)^{1}}+\ldots+\frac{C_{j T}}{(1+r)^{T}}=\sum_{t=0}^{T} \frac{C_{j t}}{(1+r)^{t}}
\end{gathered}
$$

Economic analysis can be intuitively conducted by calculating the net benefit. In this study, only PVNB was used as an index for evaluating economic efficiency. 


\subsubsection{Prerequisites for Analysis}

In this study, the social costs and benefits that have been influenced by the policy were limited to Udo. The analysis period was 18 years. Because the battery life cycle of the electric buses introduced on Udo island is nine years, this study assumed that they should be replaced once. The social discount rate and the inflation rate are $4.5 \%$ and $2 \%$, respectively (Table 2 ).

Table 2. Prerequisites for Analysis.

\begin{tabular}{|c|c|}
\hline Item & Content \\
\hline Spatial extent & Udo-myeon ${ }^{1}$, Jeju-city, Jeju-do, Republic of Korea \\
\hline Analysis period & $\begin{array}{l}\text { 2018-2035 (18 years) } \\
\text { Social cost-benefit analysis based on 2018, when electric buses were } \\
\text { introduced and operated. } \\
\text { The battery warranty period is } 9 \text { years. } \\
\text { Assume that the battery is replaced once. }\end{array}$ \\
\hline Social cost-benefit analysis subjects & $\begin{array}{l}\text { Social cost-benefit analysis subjects are governments, local residents, } \\
\text { local merchants, and tourists. }\end{array}$ \\
\hline Social discount rate & $\begin{array}{l}\text { The social discount rate is } 4.5 \% \text {, the interest rate of the market for a } \\
\text { period agreed upon by society [46]. }\end{array}$ \\
\hline Inflation rate & $\begin{array}{l}\text { The consumer price index of } 2 \% \text { [47] } \\
\text { For the calculation based on } 2018 \text { for the derived basic unit. }\end{array}$ \\
\hline
\end{tabular}

\subsubsection{Social Cost-Benefit Itemization}

The sociocultural effects of tourism are difficult to measure because they are not visible, and the effects vary from target to target, so monitoring is necessary for local assessment of the target site [48]. Thus, researchers should focus on classifying stakeholders through empirical observations, so as to make detailed inferences regarding factors that may, directly and indirectly, affect a site.

To derive the effective items of the policy, the researchers of this study visited Udo island during 12-14 July 2018 and interviewed the policymakers of Jeju province, Jeju city, and Udo-myeon local province - who can be considered policy-related stakeholders-local merchants involved in the tourism industry, and tourist. In addition, the results of an analysis of the comprehensive development plan of Udo [49] and VRP performance [28] were utilized.

This study examined the effects of Udo's VRP through cost-benefit analysis using interviews and VRP data and determined that related stakeholders include governments, local residents, local merchants, and tourists. Table 3 shows the items adopted for the social cost-benefit analysis. This study determined the scope, quantification, and valuation of each item for these subjects.

Table 3. Itemization of the Effectiveness of the Vehicle Restriction Policy in Udo.

\begin{tabular}{|c|c|c|c|}
\hline \multicolumn{2}{|c|}{ Cost } & \multicolumn{2}{|c|}{ Benefit } \\
\hline Item & Subject & Item & Subject \\
\hline $\begin{array}{l}\text { Expenses for tourism activities } \\
\text { other than transportation }\end{array}$ & Tourists & $\begin{array}{l}\text { Tourism business revenue, } \\
\text { excluding transportation }\end{array}$ & Local residents \\
\hline $\begin{array}{l}\text { Alternative transportation fee } \\
\text { (e.g., motorcycle) }\end{array}$ & Tourists & $\begin{array}{l}\text { Alternative transportation } \\
\text { rental business revenue (e.g., } \\
\text { motorcycle) }\end{array}$ & Local residents \\
\hline Electric bus fare & Tourists & $\begin{array}{l}\text { Net income from electric bus } \\
\text { operation }\end{array}$ & Local residents \\
\hline
\end{tabular}


Table 3. Cont.

\begin{tabular}{|c|c|c|c|}
\hline \multicolumn{2}{|l|}{ Cost } & \multicolumn{2}{|c|}{ Benefit } \\
\hline Item & Subject & Item & Subject \\
\hline Electric bus purchase cost & $\begin{array}{l}\text { Government, Local } \\
\text { residents }\end{array}$ & \multirow{3}{*}{$\begin{array}{l}\text { Benefits in environmental } \\
\text { pollution costs }\end{array}$} & \multirow{3}{*}{ Tourists, Local residents } \\
\hline Charging facility maintenance cost & Local residents ${ }^{1}$ & & \\
\hline Bus operation maintenance cost & Local residents ${ }^{1}$ & & \\
\hline Social conflict & $\begin{array}{l}\text { Local residents, Local } \\
\text { merchants }\end{array}$ & Urban image improvement & Local residents \\
\hline $\begin{array}{l}\text { Alternative transportation traffic } \\
\text { congestion }\end{array}$ & $\begin{array}{l}\text { Tourists, Local residents, } \\
\text { Local merchant }\end{array}$ & $\begin{array}{l}\text { Benefits of reducing traffic } \\
\text { congestion }\end{array}$ & Tourists, Local residents \\
\hline
\end{tabular}

3.1.4. Willingness to Pay Survey Using the Contingent Valuation Method for Estimating Social Benefits

It is difficult to directly quantify the economic value of benefits because these benefits are goods that are not traded in the market. To estimate the benefits of reducing traffic congestion as a social benefit, it is necessary to determine the willingness to pay (WTP) for the benefits. A questionnaire was used to set up a virtual market of environmental change. The congestion reduction benefit due to traffic volume reduction was derived through the CVM, which was estimated using the WTP to conserve the environmental improvements by local residents and tourists.

The survey was designed in accordance with the CVM guidelines to measure the contingent values [50]. The survey subjects were divided into residents and tourists. The respondents' opinions on the benefits were elicited by evaluating their satisfaction with the improvement in air quality and in the convenience of living, including in traffic and parking; shortening of the waiting time for boarding a ship; reduction of traffic accidents; and weakening of conflict between tourists and local residents. The questionnaire was organized so that the respondents could indicate their WTP for an environmental conservation fund to preserve the improved environment. A CVM was conducted to estimate the indirect benefits for tourists and residents resulting from the policy. A pretest was conducted on 10 graduate students, and the WTP of them was confirmed to be $\$ 1.67$. Therefore, the WTP criteria for the questionnaire were selected $\$ 1.67$, and the dichotomous choice method was applied to determine the suggested amount. After assigning the selected amount to the respondents, they were asked to answer "yes" or "no" regarding their WTP a certain mountain.

To estimate the indirect benefits for tourists and residents, a preliminary test was conducted during 2-3 July 2018. After reviewing this test, the first survey was conducted during 12-14 July 2018, and the second survey on 20 August 2019, to supplement the first survey.

The overall WTP was derived from the WTP of the sampled 30 residents and 30 tourists. According to the central limit theorem, if the number of the sample observations is at least 30 , the sample statistically follows the normal distribution [51].

\subsection{Future Population in Udo and Tourism Demand}

For long-term social cost-benefit analysis of policies, it is important to determine future demand. In this study, future demand was assumed, based on past data, and used for analysis. The future population of Udo for measuring the social benefits of residents estimated using the average proportion of Udo for measuring the social benefits of residents was estimated using the average proportion of Udo residents in the total Jeju population, based on 2017 data [52] (Table 4). 
Table 4. Demand Assumption for Estimating Social Cost and Social Benefit.

\begin{tabular}{cccccc}
\hline \multirow{2}{*}{ Year } & $\begin{array}{c}\text { Future Residents } \\
\text { (1 person) }\end{array}$ & $\begin{array}{c}\text { Future Tourists } \\
\text { (1000 people) }\end{array}$ & $\begin{array}{c}\text { Number of Tourists } \\
\text { Using Electric Buses }\end{array}$ & \multicolumn{2}{c}{ Number of Vehicles } \\
\cline { 5 - 6 } & & 2040 & 780 & 57,967 & Non-Electric \\
\hline 2018 & 1817 & 2141 & 792 & 57,645 & Electric \\
2019 & 1857 & 2246 & 831 & 57,100 & 26,418 \\
2020 & 1894 & 2345 & 868 & 56,108 & 31,561 \\
2021 & 1923 & 2440 & 903 & 54,751 & 36,501 \\
2022 & 1950 & 2534 & 937 & 49,251 & 45,463 \\
2023 & 1975 & 2623 & 971 & 43,150 & 54,919 \\
2024 & 2000 & 2711 & 1003 & 36,478 & 64,849 \\
2025 & 2023 & 2795 & 1034 & 29,259 & 75,238 \\
2026 & 2046 & 2878 & 1065 & 21,517 & 86,069 \\
2027 & 2067 & 2959 & 1095 & 13,272 & 97,330 \\
2028 & 2088 & 3038 & 1124 & 4542 & 109,010 \\
2029 & 2107 & 3115 & 1152 & - & 116,442 \\
2030 & 2125 & 3191 & 1181 & - & 119,277 \\
2031 & 2143 & 3265 & 1208 & - & 122,063 \\
2032 & 2159 & 3338 & 1235 & - & 124,803 \\
2033 & 2174 & 3411 & 1262 & - & 127,503 \\
2034 & 2188 & 3482 & 1288 & - & 130,165 \\
2035 & 2200 & & & & \\
\hline
\end{tabular}

Udo has been undergoing a change in tourism conditions as it learns to manage its overtourism problem. Jeju province's policy direction toward carbon-free islands has led to a regulatory policy of restricting vehicle entry rather than focusing on tourism development. This study reviewed this policy. Therefore, this study did not attempt to estimate the future tourism demand using theoretical forecasting models but estimated it by applying the ratio of the number of tourists in Udo to that of tourists in Jeju [53] from 2008 to 2017, which included the demand for Udo's tourism after the policy was implemented.

To estimate the demand for tourists who use electric buses, the proportion of electric bus use among tourists was calculated. Demand for vehicle entry is based on the ratio of the number of vehicles to the number of tourists, but the results of the survey [28] on the number of tourists and the number of vehicles during the same period before and after the recent policy implementation were assumed. The average percentage of tourists in Udo compared to the number of tourists in Jeju was $12.3 \%$ from 2008 to 2017 , and was $13 \%$ only in 2017.

Jeju province has set up a step-by-step plan to ensure that $40 \%$ of all vehicles are electric by 2022 and $100 \%$ by 2030 . This is one of the strategies for realizing a carbon-free island. Thus, the demand for future vehicles in Udo was divided into non-electric and electric.

\section{Findings}

\subsection{Social Cost Analysis}

Social cost items can be divided into direct and indirect social costs. Direct social costs include parking fees at Sungsan port (because tourists cannot bring their cars to Udo island), entrance fees to Udo provincial park (because Udo is a provincial park), boarding fees for ships and alternative means of transportation to be used instead of cars, and spending on tourism except for transportation. In addition, there are the purchase and management costs of electric buses introduced by the ULCA-which consists of local residents-to provide convenient transportation for tourists who visit the island without vehicles.

Indirect social costs include social conflicts caused by the financial interests of local residents and traffic congestion due to motorcycles and tricycles-issues that are yet to be resolved. Traffic congestion and the inconvenience of motorcycles and tricycles are problems that have been remained even after the implementation of the policy, but they were excluded from the scope of this study as separate public policies were required to be studied. 
Moreover, local merchants claimed that the policy would lead to a drop in tourist visits, which would result in a decrease in their income. The decreased income of local merchants can be an indirect social cost of implementing such policies. At the time this study was conducted, when the VRP was implemented, there was a sudden drop in the number of tourists to Jeju island. When examined closely, this was not because of the policy itself, but rather the geopolitical situation in the Korean peninsula at the time. The number of Chinese tourists to Jeju decreased because of the THAAD (Terminal High Altitude Area Defense) dispute affecting the peninsula. In 2017, the number of Chinese tourists visiting Korea dropped sharply because of China's economic retaliation against the decision to deploy THAAD on the Korean Peninsula.

Therefore, the decline in the number of tourists to Udo island in 2017 cannot be attributed to the VRP. Udo can only be accessed from Jeju island. Even though tourists might experience some inconvenience because of the policy, it does not significantly influence their decision to visit. Thus, the scope of this study excluded any reduction in income of local merchants that might be indirect social costs. The VRP costs include the purchase cost for electric buses incurred by residents of ULCA, vehicle maintenance expenses, and tourists' electric bus fares (Table 5).

1. Electric bus purchase cost: The total cost of purchasing covers 20 electric buses, including subsidies from the central and local governments, amounted to $\$ 0.24$ million per vehicle.

2. Electric bus maintenance cost: Vehicle management costs include the cost of replacing the battery (about $30 \%$ of the vehicle cost after nine years, the battery warranty period), maintaining charging facilities, and operating the buses. Thus, vehicle maintenance costs were calculated by summing up the costs incurred on these aspects of vehicle maintenance [54].

3. Electric bus fares: Electric bus fares generated from tourists and managed by ULCA have become a source of income for residents. This item should be counted twice because it will be deducted as an expense item under electric bus maintenance costs; this aspect is not calculated in the cost portion. In terms of benefits, the net profit from electric bus operation, excluding electric bus maintenance expenses, was calculated based on electric bus operation sales.

The GHGs, resulting from the production of electricity for fuel for the electric buses, were omitted. This is also a part of the cost of environmental pollution but was excluded from this current study, which limited the study's parameters to the island of Udo only.

Table 5. Social Cost Items of the Vehicle Restriction Policy in Udo.

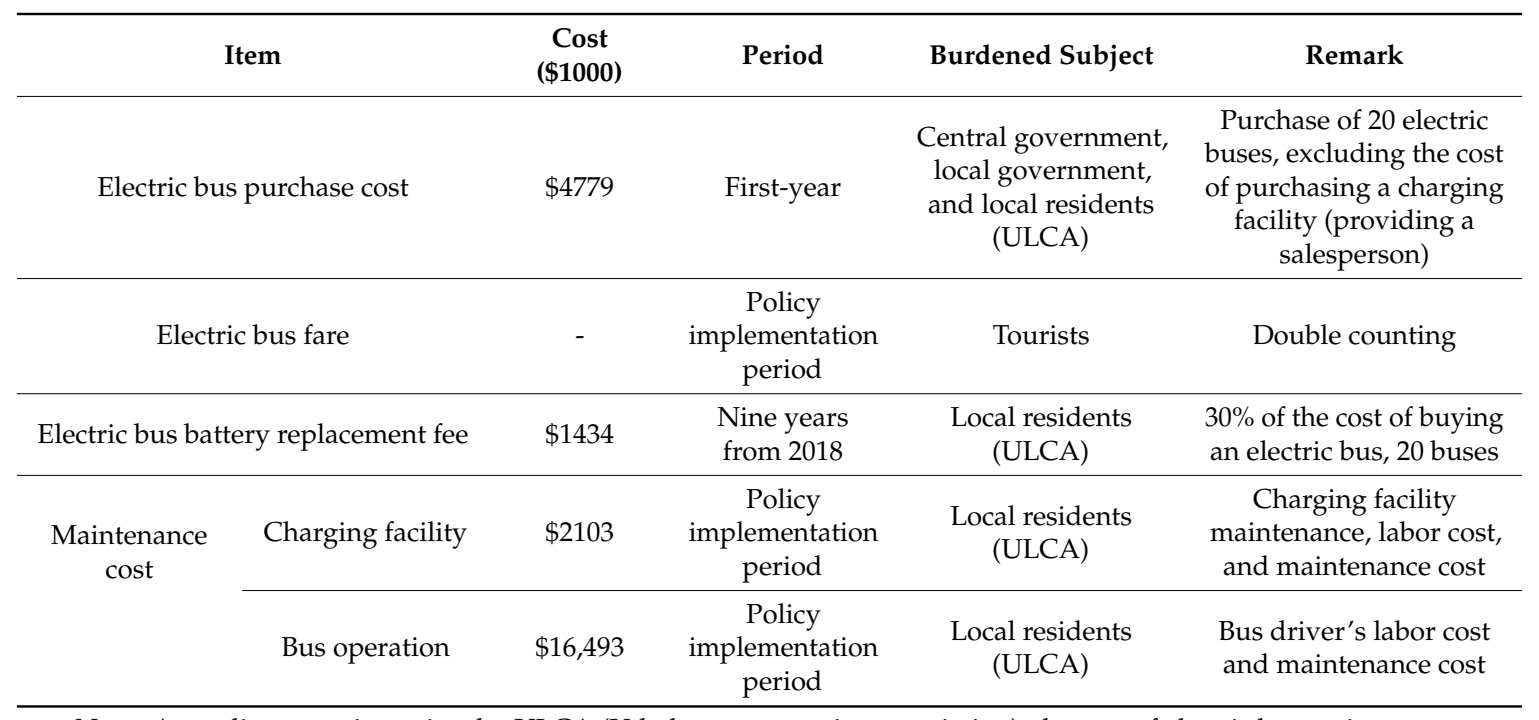

Note: According to an interview by ULCA (Udo love cooperative association), the cost of electric bus maintenance is $\$ 3.1$ for $200 \mathrm{~km}$ of service. Adjusted for $\$ 1=1136.63$ won. 


\subsection{Social Benefit Analysis}

Social benefits can be divided into direct and indirect social benefits. Direct social benefits include profits from shipping operations to local people (ULCA) and local merchants, profits from electric bus operation, alternative transportation (e.g., motorcycle), rental business revenue, revenue from tourism business, excluding transportation, and taxes paid to the governments. Profits from shipping operations are transfer prices from the costs of tourists, local residents, and local merchants. Local merchants' income from rental alternative transportation, as well as tourism revenue other than from transportation, are also transfer prices from tourists' costs. In addition, the tax increase from the implementation of the VRP is the transfer pricing of the parking fee at Sungsan port and the entrance fee to the provincial park. However, the net profit from the operation of electric buses excludes the charging and maintenance of electric buses from the electric bus fare by tourists.

It is important to derive indirect social benefits from this policy because direct social benefits are mostly transfer prices from direct social costs. Looking at the positive changes caused by the VRP because of the reduction in the number of vehicles, ships' boarding figures have improved, and traffic congestion has reduced. These environmental changes are indirect social benefits for tourists and local residents (Table 6).

1. The net profit from operating an electric bus: The net profit from operating an electric bus is the operating cost of the bus subtracted from the total tourist expenditure. This was derived by excluding the operating and managing costs of electric buses after applying a payment amount of $\$ 4.4$ per capita.

2. The economic value of the traffic congestion reduction benefits: Local residents and tourists have been asked about the amount that is WTP to preserve the various benefits of reduced traffic congestion. The local residents' WTP derived from 30 samples was $\$ 0.88$; the tourists' WTP derived from 30 tourist samples was $\$ 1.23$.

The environmental pollution cost reduction benefits: The benefit from reduced environmental pollution was calculated by modifying the air pollution costs of passenger cars proposed by the revised standard of the guidelines, published by Korea Development Institute (KDI) [55]. The air pollution costs of a passenger car are divided by types and speed. The maximum speed of a passenger car adopted in this study was $35 \mathrm{~km} / \mathrm{h}$ because passenger cars should be driven on the same roads with alternative transportation (e.g., two- or three-wheel vehicles) in Udo island.

Table 6. Social Benefit Items of the Vehicle Restriction Policy in Udo.

\begin{tabular}{ccccc}
\hline Item & Benefit $\mathbf{( \$ 1 0 0 0 )}$ & Period & $\begin{array}{c}\text { Beneficiary } \\
\text { Subject }\end{array}$ & Remark \\
\hline $\begin{array}{c}\text { Net profit of } \\
\text { electric bus } \\
\text { operation }\end{array}$ & $\$ 63,903.060$ & $\begin{array}{c}\text { Policy } \\
\text { implementation } \\
\text { period }\end{array}$ & $\begin{array}{c}\text { Local residents } \\
\text { (ULCA) }\end{array}$ & $\begin{array}{c}\text { The electric bus fare is } \$ 4.4 \\
(2018)\end{array}$ \\
\hline $\begin{array}{c}\text { Traffic congestion } \\
\text { reduction benefit }\end{array}$ & $\$ 62,298.67$ & $\begin{array}{c}\text { Policy } \\
\text { implementation } \\
\text { period }\end{array}$ & $\begin{array}{c}\text { Tourists, local } \\
\text { residents, local } \\
\text { merchants }\end{array}$ & WTP of local residents is $\$ 0.88$, \\
WTP of tourists is $\$ 1.23$
\end{tabular}

Note: Adjusted for $\$ 1=1136.63$ won.

The benefit of reducing the cost of environmental pollution caused by the reduction in traffic congestion, and the net profit by item from operating electric buses according to the estimated future demand, can be regarded as a social benefit, as shown in Table 7 . 
Table 7. Social Benefits Estimation before Applying the Discount Rate.

\begin{tabular}{|c|c|c|c|c|}
\hline \multirow{2}{*}{ Year } & \multirow{2}{*}{$\begin{array}{c}\text { Net Profit from } \\
\text { Electric Bus } \\
\text { Operation }\end{array}$} & \multicolumn{2}{|c|}{ Traffic Congestion Reduction Benefit } & \multirow{2}{*}{$\begin{array}{l}\text { Environmental } \\
\text { Pollution Cost } \\
\text { Reduction Benefit }\end{array}$} \\
\hline & & $\begin{array}{l}\text { Local Residents, } \\
\text { Local Merchants }\end{array}$ & Tourists & \\
\hline 2018 & 2484.2 & 1.60 & 2513.0 & 26.4 \\
\hline 2019 & 2535.0 & 1.63 & 2637.9 & 26.2 \\
\hline 2020 & 2693.2 & 1.67 & 2766.7 & 26.0 \\
\hline 2021 & 2843.0 & 1.69 & 2888.5 & 25.5 \\
\hline 2022 & 2988.1 & 1.72 & 3006.6 & 24.9 \\
\hline 2023 & 3128.3 & 1.74 & 3120.7 & 22.4 \\
\hline 2024 & 3264.2 & 1.76 & 3231.2 & 19.6 \\
\hline 2025 & 3396.1 & 1.78 & 3338.6 & 16.6 \\
\hline 2026 & 3524.5 & 1.80 & 3443.0 & 13.3 \\
\hline 2027 & 3649.6 & 1.82 & 3544.8 & 9.8 \\
\hline 2028 & 3771.7 & 1.84 & 3644.2 & 6.0 \\
\hline 2029 & 3891.2 & 1.85 & 3741.4 & 2.1 \\
\hline 2030 & 4008.2 & 1.87 & 3836.6 & - \\
\hline 2031 & 4123.1 & 1.89 & 3930.0 & - \\
\hline 2032 & 4235.9 & 1.90 & 4021.8 & - \\
\hline 2033 & 4346.9 & 1.91 & 4112.1 & - \\
\hline 2034 & 4456.2 & 1.92 & 4201.0 & - \\
\hline 2035 & 4564.0 & 1.94 & 4288.7 & - \\
\hline
\end{tabular}

Note: Adjusted for $\$ 1=1136.63$ won.

\subsection{Social Cost-Benefit Analysis}

The total benefit is the sum of the following calculations: the sum of the residents' and tourists' WTP for the maintenance of the improved tourism environment, due to the reduction of traffic congestion, multiplied by the numbers of residents and tourists respectively; the net profit from the electric bus operation; and the benefit from air pollution reduction, due to vehicle entry limitation.

To evaluate the future value at the present-day value, the total benefit and total cost were adjusted for the diminished value of the investment of time.

As a result of the calculations above, the present value of the benefit (PVB) was estimated to be $\$ 5$ million for 2018, the year in which the policy was implemented. The PVB for 2035, the final year of review, was expected to reach $\$ 4.2$ million.

The present value of cost (PVC) of purchasing 20 electric buses in 2018, the initial year of the VRP, was high, at approximately $\$ 5.7$ million. After the initial calculations of expenses on merchandise, the costs for the management and maintenance of charging facilities and bus operations were calculated. It was estimated that the PVC would be $\$ 0.5$ million in 2035, considering the expansion of the electric bus service and the change in tourist demand every year. However, in the eighth year (2026), it was estimated that replacing the electric battery in the bus would incur an additional expenditure of $\$ 2464$ per unit.

If the present value of the net benefit (PVNB) is applied to the net benefit by year, the PVNB for the first year, 2018, has a loss of $\$ 0.7$ million. However, if the first year is calculated from the standard of 18 years, the PVNB continues to gain over time around $\$ 4$ million per year, except during the eighth year (2026), the year in which battery replacement is required (Table 8). 
Table 8. Present Value of Net Benefit by Year.

\begin{tabular}{cccc}
\hline Year & PVC (\$1000) & PVB (\$1000) & PVNB (\$1000) \\
\hline 2018 & 5699.3 & 5026.3 & -672.9 \\
2019 & 910.1 & 4978.0 & 4067.9 \\
2020 & 881.8 & 5026.3 & 4144.5 \\
2021 & 853.7 & 5047.5 & 4193.8 \\
2022 & 826.1 & 5050.4 & 4224.3 \\
2023 & 798.9 & 5035.0 & 4236.1 \\
2024 & 772.4 & 5005.4 & 4232.9 \\
2025 & 746.4 & 4963.5 & 4217.1 \\
2026 & 1723.5 & 4911.2 & 3187.7 \\
2027 & 696.3 & 4850.1 & 4153.7 \\
2028 & 672.3 & 4781.5 & 4109.2 \\
2029 & 648.8 & 4706.7 & 4057.9 \\
2030 & 626.1 & 4628.0 & 4001.9 \\
2031 & 603.9 & 4546.2 & 3942.3 \\
2032 & 582.6 & 4461.0 & 387834 \\
2033 & 561.8 & 4372.9 & 3811.1 \\
2034 & 541.6 & 4282.7 & 3741.1 \\
2035 & 522.2 & 4190.8 & 3668.7 \\
\hline
\end{tabular}

Note: Adjusted for the diminished value of $4.5 \%$ for PVC, PVB, and PVNB (PVC = present value of cost, $\mathrm{PVB}=$ present value of the benefit, PVNB = present value of net benefit). Adjusted for $\$ 1=1136.63$ won.

\section{Discussion and Conclusions}

Udo island prioritized solving the problem of overtourism caused by traffic congestion - which is consistent with the global problem of climate change-over the congestion problem. The policy restricting vehicle entry-initially introduced to eliminate the visible effects of excessive cars and improve those of overtourism—has the added benefit of reducing air pollution, thus helping Jeju island's transformation into a carbonless island.

This study used the vehicle restriction policy of Udo island in South Korea to perform an economic feasibility analysis of the social cost-benefit of multiple stakeholders: government, local residents, local merchants, and tourists. Despite the fact that Udo's current policy to restrict the entry of vehicles has been introduced to manage the problems caused by overtourism in the region, conflicts among stakeholders in the region have evolved.

This study conducted an economic analysis to examine what each stakeholder could lose or gain from the policy's implementation. The analysis results showed that there is, in fact, a net benefit derived from the VRP implementation.

Even though tourists are likely to pursue convenience, they can embrace systems based on the values for sustaining sound economic, environmental, and socio-cultural areas, contrary to the concern of local merchants who were suing the government, and implying their decreased revenue was due to the VRP not being convenient for tourists. The analysis results showed that those who oppose the VRP for the convenience of tourists, and hence revenue generation, are, in fact, not persuasive. These policies are even more valuable to tourists than to the local residents because tourists have been shown to support these policies despite their personal inconvenience.

The value of the anti-overtourism policy for local residents and tourists to derive environmental benefits was measured through CVM analysis. Through this analysis, this study was able to discover the possibility of areas where locals and tourists could coexist.

Overtourism should always be considered in the management of a region's tourism development and be kept in mind as a target to avoid regional tourism growth [3,20]. Authentic management policy for the sustainability of the region should always be promoted. The problem of overtourism cannot be solved in the short term [11]. Social conflicts that arise because of policy implementation against 
overtourim due to varied stakeholder interests can be mitigated gradually if the long-term analysis is permitted.

Despite including various assumptions, the quantitative evaluation of policy through economic analysis helps one intuitively recognize the effects of policy implementation. In reality, the position of various policy-related stakeholders differs, and the effect of policy execution can be determined specifically by deriving the net benefit expected.

According to the results of this study's cost-benefit analysis, the present value of net benefit would be $\$ 4.1$ million from 2019 after the implementation of the policy in 2018, and the present value of net benefit would reach $\$ 3.7$ million in 2035 after an 18-year policy implementation period. As a result, the net benefit would continue to be around $\$ 4$ million from the year following the implementation of the policy. Therefore, this study concluded that the policy of restricting entry of vehicles is economically sound.

Management policies in the tourism and transportation sectors that consume high energy and have a great impact on climate change are extremely necessary; however, it is practically difficult to implement policies that can satisfy everyone's needs. Although there are difficulties in implementing the current policy due to opposition from local merchants because of declines in economic profits in the short term, the focus should always be on implementing policy with high net future benefits.

Because of the failure of the overtourism system [10], tourists must endure inconvenience in the face of overtourism; however, the implementation of policies to manage overtourism can ensure the physical sustainability of a region and the sustainability of the community. In addition, by providing a pleasant tourism experience with proper management, tourist satisfaction can be improved, thereby securing the sustainability of tourism destinations and ultimately securing economic sustainability. Therefore, although conflicts may occur in the early stages of policy implementation, appropriate management policy is essential to secure regional sustainability.

A more sophisticated forecasting model design that can calculate various demand estimates that might not have been considered in this study is necessary for future research. Further analysis of this policy may consider supplementing the current research methodology. This study might contribute to the body of literature available in this area for future studies by other researchers in other regions concerned with similar policy implementations with regards to overtourism.

Author Contributions: Conceptualization, S.K.; methodology, S.K.; data curation, S.K.; analysis, S.K.; theoretical implications; S.K.; writing —original draft preparation, S.K.; writing—review and editing, N.K.; supervision, N.K. All authors have read and agreed to the published version of the manuscript.

Funding: This research received no external funding.

Conflicts of Interest: The authors declare no conflict of interest.

\section{References}

1. Lee, S.H. Pre-overtourism phenomena and warning: Looking back on the lives of Jeju residents as reported by local media. Korean J. Commun. Inf. 2018, 88, 77-109.

2. Alvarez-Sousa, A. The problems of tourist sustainability in cultural cities: Socio-political perceptions and interests management. Sustainability 2018, 10, 503. [CrossRef]

3. World Travel and Tourism Council (WTTC). Coping with Sustainable, Managing Overcrowding in Tourism Destinations. Available online: https:/www.wttc.org/-/media/files/reports/policy-research/coping-with-suc cess---managing-overcrowding-in-tourism-destinations-2017.pdf (accessed on 15 September 2018).

4. Jeju Vehicle Restriction Court Ending. Available online: http://www.jejusori.net/news/articleView.html?idx no=202421 (accessed on 10 December 2018).

5. Goodwin, H. The Challenge of Overtourism. Responsible Tourism Partnership Working Paper 4. 2017. Available online: https://haroldgoodwin.info/pubs/RTP\%27WP4Overtourism01\%272017.pdf (accessed on 10 December 2018). 
6. Park, J.Y. The Emergence of, and Responding to Overtourism; Korea Culture and Tourism Institute: Seoul, Korea, 2018; pp. 18-30.

7. Son, S.W.; Park, S.H.; Lee, N.H. Exploratory study of national policy measures on overtourism and sustainable tourism industry. J. Tour. Manag. Res. 2018, 22, 331-354. [CrossRef]

8. UNWTO. Overtourism?: Understanding and Managing Urban Tourism Growth Beyond Perceptions; The World Tourism Organization (UNWTO): Madrid, Spain, 2018; pp. 3-8.

9. Brown, S. Why Overtourism Matters and What to Do about It (Web Log Comment). Available online: https://sa mantha-brown.com/tips/why-overtourism-matters-and-what-to-do-about-it (accessed on 22 October 2018).

10. Alexis, P. Overtourism and anti-tourist sentiment: An exploratory analysis and discussion. Econ. Sci. Ser. 2017, 17, 288-293.

11. Francis, J. The Real Cause of Overtourism. Available online: https://www.responsibletravel.com/copy/blogpost-forty (accessed on 20 October 2018).

12. UNWTO. 'Overtourism': Growth is not the enemy, it is how we manage it. In Proceedings of the UNWTO and WTM Ministers' Summit, London, UK, 7 November 2017.

13. Bows, A.; Anderson, B.; Peeters, P.M. Air transport, climate change and tourism. Tour. Hosp. Plan. Dev. 2009, 6, 7-20. [CrossRef]

14. Peeters, P.; Dubois, G. Tourism travel under climate change mitigation constraints. J. Transp. Geogr. 2010, 18, 447-457. [CrossRef]

15. UNEP. International Year of Ecotourism. Available online: https://www.un.org/press/en/2002/envdev607.doc .htm (accessed on 20 October 2018).

16. Pan, S.-Y.; Gao, M.; Kim, H.O.; Shah, K.J.; Pei, S.L.; Chiang, P.C. Advances and challenges in sustainable tourism toward a green economy. Sc. Total Environ. 2018, 635, 452-469. [CrossRef]

17. Rico, A.; Martínez-Blancoa, J.; Rodríguezc, G.; Tavaresc, N.; Ariasd, A.; Oliver-Solà, J. Carbon footprint of tourism in Barcelona. Tour. Manag. 2019, 70, 491-504. [CrossRef]

18. UNEP; UNWTO. Tourism in the Green Economy: Background Report; World Tourism Organization (UNWTO): Madrid, Spain, 2012; p. 167.

19. UNWTO; UNEP; WMO. Climate Change and Tourism. Responding to Global Challenges; World Tourism Organization (UNWTO): Madrid, Spain, 2008.

20. Lumsdon, L. Transport and Tourism: Cycle Tourism-A Model for Sustainable Development? J. Sustain. Tour. 2000, 8, 361-377. [CrossRef]

21. ETE. Sustainable Tourism Development in UNESCO Designated Sites in South-Eastern Europe; Ecological Tourism in Europe (ETE): Bonn, Germany, 2009.

22. Kim, M.S. Analysis of the Economic Feasibility of a Monorail on Mt. Bomun on Daejeon. J. Korean Soc. Railw. 2013, 16, 226-232. [CrossRef]

23. Gössling, S.; Choi, A.S. Transport transitions in Copenhagen: Comparing the cost of cars and bicycles. Ecol. Econ. 2015, 113, 106-113. [CrossRef]

24. Hwang, K.S.; Ko, T.H.; Hong. C.S. The measurement of social carrying capacity on the total amount of vehicles for estimation of the appropriate number of vehicles in Udo island. Korean Soc. Civ. Eng. 2009, $29,605-610$.

25. Ko, K.B.; Hwang, K.S.; Kim, K.B. The monitoring and persistence on the total amount of vehicles in Udo island. J. Korea Acad.-Ind. Coop. Soc. 2016, 17, 471-480.

26. Jeju Special Self-Governing Province-Jeju City Establishes Transportation and Environmental Regulation Policy. Available online: http://www.jejusori.net/?mod=news\&act=articleView\&idxno=181367 (accessed on 10 December 2018).

27. Implementation of the Vehicle Restriction Policy in Udo. Available online: http://www.newsje.com/news/arti cleView.html?idxno=110764 (accessed on 8 December 2018).

28. Jeju Special Self-Governing Province. An Analysis of One-Year Performance of Restrictions on the Operation of Some Cars in Udo-Myeon. Public Hearing Material; Jeju Special Self-Governing Province: Jeju, Korea, 2018.

29. Kim, H.B. Public Policy Analysis and Evaluation Method: A Cost-Benefit Analysis; Nanam Pess: Paju, Korea, 2012; pp. 17-150.

30. Boardman, A.E.; Greenberg, D.H.; Vining, A.R.; Weimer, D.L. Cost-Benefit Analysis: Concepts and Practice, 4th ed.; Pearson Education: Essex, UK, 2014; pp. 17-235. 
31. Fuguitt, D.; Wilcox, S.J. Cost-Benefit Analysis for Public Sector Decision Makers; Quorum Books: London, UK, 1999; pp. 12-30.

32. Keating, B.P.; Keating, M.O. Basic Cost Benefit Analysis for Assessing Local Public Projects; Business Expert Press: New York, NY, USA, 2014; pp. 8-20.

33. Seo, S.A. A Comparative Study on Social Cost and Benefit Analysis; Korea Institute of Public Administration: Seoul, Korea, 2017; pp. 5-27.

34. Schofield, J. Cost-Benefit Analysis in Urban \& Regional Planning; Allen \& Unwin: London, UK, 1987; pp. 1-5.

35. Hong, C.S. A study on the cost benefit analysis of tourism investment. J. Tour. Policy 2004, 10, 113-132.

36. Renda, A.; Schrefler, L.; Luchetta, G.; Zavatta, R. Assessing the Costs and Benefits of Regulation. Available online: https://ec.europa.eu/smart-regulation/impact/commission_guidelines/docs/131210_cba_study_sg_ final.pdf (accessed on 10 November 2018).

37. Ruijs, A. The role of social cost-benefit analysis revisited: The role of CBA in river basin management in the Netherlands. In Proceedings of the Final Conference of the Fruede am Fluss Project, Nijmegen, The Netherlands, 22-24 October 2008.

38. Jones-Lee, M.; Aven, T. The role of social cost-benefit analysis in societal decision-making under large uncertainties with application to robbery at a cash depot. Reliab. Eng. Sys. Saf. 2009, 94, 1954-1961. [CrossRef]

39. Kirkby, C.A.; Giudice-Granados, R.; Day, B.; Turne, K.; Velarde-Andrade, L.M.; Duenas-Duenas, A.; Lara-Rivas, J.C.; Yu, D.W. The market triumph of ecotourism: An economic investigation of the private and social benefits of competing land uses in the Peruvian Amazon. PLoS ONE 2010, 5, 1-14. [CrossRef]

40. Bianchini, F.; Hewage, K. Probabilistic social cost-benefit analysis for green roofs: A life cycle approach. Build. Environ. 2012, 58, 152-162.

41. Cantuarias-Villessuzanne, C.; Weinberger, B.; Roses, L.; Vignes, A.; Brignon, J. Social cost-benefit analysis of hydrogen mobility in Europe. Int. J. Hydrogen Energy. 2016, 41, 19304-19311. [CrossRef]

42. Dwyer, L.; Jago, L.; Forsyth, P. Economic evaluation of special events: Reconciling economic impact and cost-benefit analysis. Scand. J. Hosp. Tour. 2016, 16, 115-129. [CrossRef]

43. Kwack, S.J. Analysis and Implication of SOC Account in Aviation Sector; National Assembly Research Service: Seoul, Korea, 2014; pp. 28-30.

44. Kwack, H.K.; Kim, I.R. Study on benefit-cost factors on community organization participation: Focusing on the resident autonomy center. Korean. Assoc. Local Gov. Stud. 2006, 10, 185-210.

45. Hwang, K.S.; Ko, T.H. Estimation of economic value of natural resource: The case of Songak mountain tourism zone. Korean. J. Local. Gov. Stud. 2004, 8, 51-72.

46. Korea Ministry of Economy and Finance. Korea Ministry of Economy and Finance Report. Available online: http://www.moef.go.kr/synapView/previewTop.jsp?CastExtn=HWP\&orignlFileNm=170811_\%EC\%98\%88

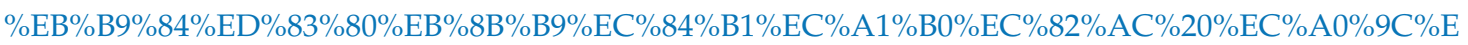

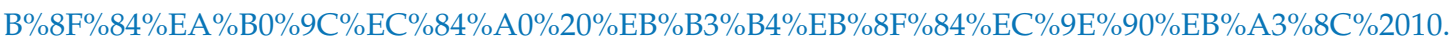
hwp\&atchFileId=ATCH_000000000005910\&fileSn=1 (accessed on 7 December 2018).

47. Statistics Korea, November 2018 Consumer Price Trends. Available online: https://www.gov.kr/portal/ntna dmNews/1692251 (accessed on 7 December 2018).

48. Liu, J.C.; Sheldon, P.J.; Var, T. Resident perception of the environmental impacts of tourism. Ann. Tour. Res. 1987, 14, 17-37. [CrossRef]

49. Jeju City. An Analysis on the Comprehensive Development Plan of Udo; Jeju City: Jeju, Korea, 2018; pp. $28-50$.

50. KDI. A Study on the Improvement of CVM Analysis Guidelines for Preliminary Feasibility Study. Available online: https://www.kdi.re.kr/research/subjects_view.jsp?pub_no=13495 (accessed on 23 November 2018).

51. Brian, P.M.; Philip, M.N. Applied Statistics for Public Policy; M.E. Sharpe: New York, NY, USA, 2006; p. 166.

52. Jeju Special Self-Governing Province. Future Population Estimate of Jeju Island. Available online: https://www.jeju.go.kr/open/stats/news.htm;jsessionid=PMGr2p5yb4buv6TbNHAYxOCITqrdrZqhqhW1 idNFuBJNNqrc0ZURvIpRGzwilWGf.was2_servlet_engine1?page=4\&act=view\&seq=1034145 (accessed on 11 October 2018).

53. Jeju Tourism Organization. A Study on Comprehensive Carrying Capacity of Jeju Island; Jeju Tourism Organization: Jeju, Korea, 2017. 
54. Yook, D.K.; Kim, W.K.; Choi, Y.G.; Oh, I.S. Economic Evaluation Based on the Introduction of Eco-Friendly Public Transportation System: Focusing on Bus Route by Types. In Proceedings of the Spring Conference of the ITS Society of Korea, Seoul, Korea, 16-17 February 2017.

55. KDI. A Study on the Revision and Complementary Research of the Standard Guidelines for Preliminary Feasibility Study of Road and Railway Projects. Available online: https://www.kdi.re.kr/research/subjects_vi ew.jsp?pub_no=11672 (accessed on 23 November 2018).

(C) 2020 by the authors. Licensee MDPI, Basel, Switzerland. This article is an open access article distributed under the terms and conditions of the Creative Commons Attribution (CC BY) license (http://creativecommons.org/licenses/by/4.0/). 